\title{
Elucidation of in-vitro anti-inflammatory bioactive compounds isolated from Jatropha curcas L. plant root
}

Ahmad Razi Othman ${ }^{1+}$, Norhani Abdullah ${ }^{2,3^{*}}$, Syahida Ahmad $^{2+}$, Intan Safinar Ismail ${ }^{1,4+}$ and Mohamad Pauzi Zakaria ${ }^{5+}$

\begin{abstract}
Background: The Jatropha curcas plant or locally known as "Pokok Jarak" has been widely used in traditional medical applications. This plant is used to treat various conditions such as arthritis, gout, jaundice, wound and inflammation. However, the nature of compounds involved has not been well documented. Hence, this study was conducted to investigate the anti-inflammatory activity of different parts of $J$. curcas plant and to identify the active compounds involved.
\end{abstract}

Methods: In this study, methanol (80\%) extraction of four different parts (leaves, fruits, stem and root) of J. curcas plant was carried out. Phenolic content of each part was determined by using Folin-Ciocalteau reagent. Gallic acid was used as the phenol standard. Each plant part was screened for anti-inflammatory activity using cultured macrophage RAW 264.7 cells. The active plant part was then partitioned with hexane, chloroform, ethyl acetate and water. Each partition was again screened for anti-inflammatory activity. The active partition was then fractionated using an open column chromatography system. Single spots isolated from column chromatography were assayed for anti-inflammatory and cytotoxicity activities. Spots that showed activity were subjected to gas chromatography mass spectrophotometry (GC-MS) analysis for identification of active metabolites.

Results: The hexane partition from root extract showed the highest anti-inflammatory activity. However, it also showed high cytotoxicity towards RAW 264.7 cells at $1 \mathrm{mg} / \mathrm{mL}$. Fractionation process using column chromatography showed five spots. Two spots labeled as $\mathrm{H}-4$ and $\mathrm{H}-5$ possessed anti-inflammatory activity, without cytotoxicity activity. Analysis of both spots by GC-MS showed the presence of hexadecanoic acid methyl ester, octadecanoic acid methyl ester and octadecanoic acid.

Conclusion: This finding suggests that hexadecanoic acid methyl ester, octadecanoic acid methyl ester and octadecanoic acid could be responsible for the anti-inflammatory activity of the J. curcas root extract.

Keywords: Plant parts, Hexane extract, Hexadecanoic acid methyl ester, Octadecanoic acid methyl ester, Octadecanoic acid

\footnotetext{
* Correspondence: norhani@upm.edu.my

${ }^{\dagger}$ Equal contributors

${ }^{2}$ Department of Biochemistry, Faculty of Biotechnology and Biomolecular Sciences, Universiti Putra Malaysia, 43400 Serdang, Selangor, Darul Ehsan, Malaysia

${ }^{3}$ Institute Of Tropical Agriculture Universiti Putra Malaysia, 43400 UPM Serdang, Selangor, Darul Ehsan, Malaysia

Full list of author information is available at the end of the article
} 


\section{Background}

Jatropha curcas Linn. (family Euphorbiaceae) is a multipurpose plant, brought by the Portuguese sailor from Mexico to the Asian region around the $16^{\text {th }}$ century to be used as shade tree and live fences for crops protection [1]. However, the plant was discovered to possess healing properties and for decades it has been used to treat arthritis, gout, jaundice and inflammation in countries such as Peru, Brazil, Mexico and Egypt [2]. Currently, increasing scientific interest focuses on the importance of bioactive compounds derived from plants including J. curcas.

A group of researchers from Malaysia reported that Jatropha poisoning occurred mainly in children due to accidental ingestion of the fruits of the plant [3]. Similar cases were also reported in India in 2003 [4]. However, to date, there is no report on the lethal effect of Jatropha in human [5]. Nevertheless, several cases involving death were reported in ruminant associated with Jatropha consumption during the dry season [6].

It has been shown that the root of $J$. curcas exerts a significant anti-inflammatory effect in bioassay studies $[7,8]$. Unfortunately, the root of J. curcas does not only exert beneficial anti-inflammatory effect, but it also shows toxic effects on humans, animals and cell lines. A study conducted in Brazil found that the tribes using $J$. curcas roots as traditional medicine were advised to take extra precaution due to the toxicity of the plant [2]. These results indicated that the $J$. curcas root contains compounds with anti-inflammatory as well as cytotoxic activities.

Thus, the main aim of this study was to elucidate the nature of bioactive compounds with anti-inflammatory and cytotoxic activities present in J. curcas plant.

\section{Methods}

\section{Sample collection}

Jatropha curcas L. plant aged approximately 5 years was collected from Farm 2, Faculty of Agriculture, Universiti Putra Malaysia (UPM) and verified by the botanist, Dr. Shamsul Khamis at the Institute of Bioscience, UPM. The plant was deposited in the Phytomedicinal Herbarium, Institute of Bioscience, UPM with voucher number (SK1764/2010). Three plants were bought to the laboratory and distributed into leaves, fruits, stems and roots.

\section{Preparation of plant crude extract}

All plant parts were cut into small pieces $(2 \mathrm{~mm}$ to $5 \mathrm{~mm}$ ), dried using a freeze drier and ground to a powder form. Subsequently, $10 \mathrm{mg}$ of dried powdered samples were transferred into the $250 \mathrm{~mL}$ bottle. Samples were then soaked in $200 \mathrm{~mL} 80 \%$ methanol for 24 hours. The samples were filtered through Whatman filter paper No. 1 and the filtrate was kept in $1 \mathrm{~L}$ bottle and stored at $4^{\circ} \mathrm{C}$. The residue was re-extracted with the same volume of $80 \%$ methanol every day for five days until the solvent color became clear. All filtrates were pooled and dried using a rotary evaporator at $40^{\circ} \mathrm{C}$ with constant pressure. Dried extracts were labeled as crude extracts and stored at $-20^{\circ} \mathrm{C}$ for screening of anti-inflammatory activity [7].

\section{Liquid - liquid partition}

The dried methanolic extract (6.4 g) was dissolved in $1 \mathrm{~L}$ of double distilled water before undergoing liquid-liquid partition. Three types of solvents (hexane, chloroform, ethyl acetate) with different polarities were used as described by Rajbir et al. [9]. Each partition was conducted three times and the eluent was pooled and dried using rotary evaporator. Dry weight of each partition was recorded as total yield.

\section{Phenolic content}

Phenolic content of crude extract was determined by using Folin Ciocalteau method, using gallic acid as the standard. Twenty $\mathrm{uL}$ of crude extract $(1 \mathrm{~g} / \mathrm{mL})$ were added into $1.58 \mathrm{~mL}$ of distilled deionized water. A $100 \mathrm{uL}$ of Folin Ciocalteau reagent (5\%) was added and mixed thoroughly and incubated for 8 minutes at room temperature. After that, $300 \mathrm{uL}$ of concentrated sodium carbonate $\left(\mathrm{Na}_{2} \mathrm{CO}_{3}\right)$ were added and incubated for 2 hours. The absorbance was read at $765 \mathrm{~nm}$ using a spectrophotometer (Labomed, inc. model Spectro 23). A gallic acid standard (0-0.05 mg) was prepared accordingly. The phenolic content was expressed as milligram of gallic acid equivalent (GAE) per gram of dried samples (mg GAE/g dw).

\section{Anti-inflammatory and cytotoxicity assays}

Murine monocytic macrophage cell line RAW 264.7 purchased from American Type Culture Collection (ATCC) was cultured in Dulbecco's Modified Eagle Media (DMEM) with $4 \mathrm{mM}$ L-Glutamine, $45 \mathrm{~g} / \mathrm{L}$ glucose, $1 \mathrm{mM}$ sodium pyruvate and $10 \%$ of fetal bovine serum (FBS). The cells were incubated in $50 \mathrm{~mL}$ cell culture flask placed in $\mathrm{CO}_{2}$ incubator with $5 \%$ of $\mathrm{CO}_{2}$ at $37^{\circ} \mathrm{C}$. RAW 264.7 cells were seeded in a 96-well microplate at $1 \times 10^{6}$ cell $/ \mathrm{mL}$. Seeded cells were incubated in $5 \% \mathrm{CO}_{2}$ at $37^{\circ} \mathrm{C}$ for 2 to 3 hours. One $\mathrm{mg} / \mathrm{mL}$ of samples was added to seeded cells. Cells were then stimulated with $100 \mathrm{U} / \mathrm{mL}$ of interferon-gamma (IFN- $\gamma$ ) and $5 \mathrm{ug} / \mathrm{mL}$ of lipopolysacharide (LPS) from

Table 1 Phenolic contents of different parts of $J$. curcas

\begin{tabular}{ll}
\hline Plant parts & Phenolic $(\mathbf{m g ~ G A E} / \mathbf{g ~ d w})^{*}$ \\
\hline Leaves & $1.33 \pm 0.013^{\mathrm{a}}$ \\
Root & $1.11 \pm 0.008^{\mathrm{b}}$ \\
Fruits & $0.51 \pm 0.017^{c}$ \\
Stem & $0.11 \pm 0.003^{\mathrm{d}}$ \\
\hline
\end{tabular}

*Dry weight of extract.

Means \pm standard deviation with different superscripts indicate significant difference.

$(P<0.05)$. 
Table 2 Phenolic content of $J$. curcas root in different solvents

\begin{tabular}{ll}
\hline Fractions & Phenolic $(\mathbf{m g ~ G A E} / \mathbf{g ~ d w})^{*}$ \\
\hline Water & $0.69 \pm 0.009^{\mathrm{a}}$ \\
Chloroform & $0.15 \pm 0.004^{\mathrm{b}}$ \\
Ethyl Acetate & $0.15 \pm 0.004^{\mathrm{b}}$ \\
Hexane & $0.11 \pm 0.004^{\mathrm{b}}$ \\
\hline
\end{tabular}

*Dry weight of extract.

Means \pm standard deviation with different superscripts indicate significant difference.

$(P<0.05)$.

Escherichia coli strain 055:B5. The cells were incubated in $5 \% \mathrm{CO}_{2}$ at $37^{\circ} \mathrm{C}$ for 18 hours. The nitric oxide concentration produced by RAW 264.7 cell was determined by Griess assay. N-nitro-L-arginine-methyl ester (L-NAME) as iNOS inhibitor was used as a positive control at concentration of $250 \mu \mathrm{M}$. The cytotoxicity activity of sample extract was determined using MTT (3-(4,5-dimethylthiazol-2-yl)-2,5-diphenyltetrazolium bromide) assay [10].

\section{Column chromatography analysis}

Five $\mathrm{mL}$ of mini preparative columns were prepared using silica gel 60 with 70-230 Mesh (ASTM) slurry in $100 \%$ hexane. The column was then prewashed with hexane: ethyl acetate (EtOAc) solvent at ratio 7:3. One $\mathrm{mL}$ of fraction was loaded into the column and immediately eluted with $3 \mathrm{~mL}$ of hexane: EtOAc (7:3) solution, followed by $20 \mathrm{~mL}$ of hexane: EtOAc solution (6:4). One $\mathrm{mL}$ of eluent was collected in $1.5 \mathrm{~mL}$ microcentrifuge tube in series. Each eluent was analyzed using analytical thin layer chromatography (TLC) plate.

Thin layer chromatography plate was prepared by coating a plastic plate with silica gel 60 F245 $(0.25 \mathrm{~mm}$ thick and $7.5 \mathrm{~cm}$ long). The developer solvent was hexane: EtOAc with a ratio 6:4. A developed TLC plate was then viewed under UV at wavelength $254 \mathrm{~nm}$ and $366 \mathrm{~nm}$. Spots with similar $\mathrm{R}_{\mathrm{f}}$ values were pooled and air dried for anti-inflammatory assay and metabolites identification.

\section{Gas chromatography mass spectrometry (GC-MS)}

Hexane partition of root and spot samples from TLC plates were analysed for bioactive compounds by using GC-MS QP2010 Plus SHIMADZU with SGE BPX5 column $(30 \mathrm{~m} \times 0.25 \mathrm{~mm}$, I.D $\times 0.25 \mu \mathrm{m})$. Oven temperature was set at $50^{\circ} \mathrm{C}$ to $300^{\circ} \mathrm{C}$ at $10^{\circ} \mathrm{C} / \mathrm{min}$. Injection temperature was set at $250^{\circ} \mathrm{C}$ using a splitless mode. Helium gas (99.9\%) was used as the carrier. Total GC-MS running time was 35 minutes. All peak areas were compared with the database in the GC-MS library version NIST 08-S.

\section{Statistical analysis}

All data were subjected to one-way analysis of variance (ANOVA). Treatment means were compared using Tukey's multiple comparison tests. Statistic software Graphpad Prism 5.0 (Graphpad Software Inc., San Diego, CA) was used for all statistical analyses.

\section{Results}

\section{Phenolic content}

The levels of phenolic compounds in different parts of J. curcas are shown in Table 1. Among the parts, leaves showed the highest value, followed by roots, fruits and stem. Differences among plant parts were significant $(\mathrm{P}<0.05)$. The value for leaves, roots, fruits and stem were $1.33 \mathrm{mg}$ GAE/g dw, $1.11 \mathrm{mg} \mathrm{GAE} / \mathrm{g} \mathrm{dw}, 0.51 \mathrm{mg}$ GAE/g dw and $0.11 \mathrm{mg} \mathrm{GAE} / \mathrm{g}$ dw respectively. Phenolic content for $J$. curcas root partitions is shown in Table 2. The phenolic content in water fraction was significantly

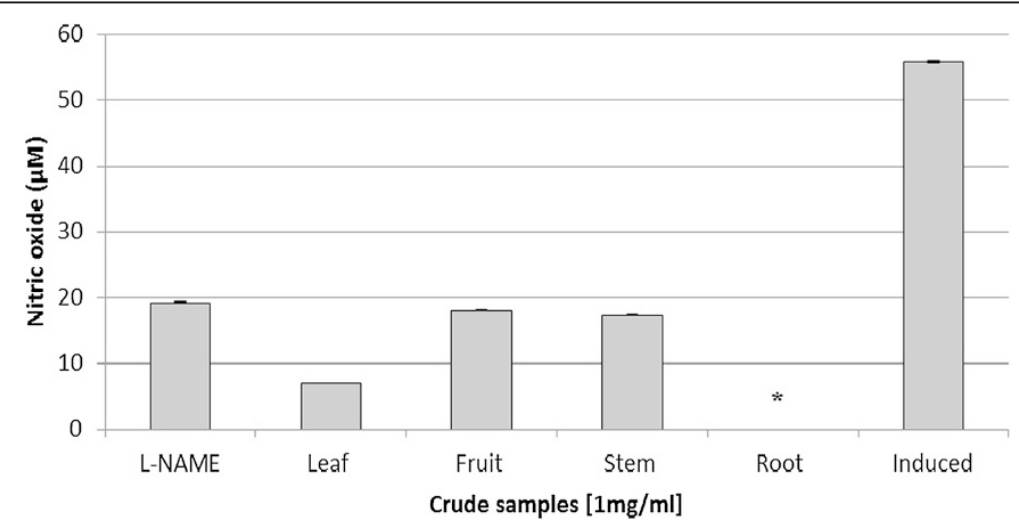

Figure 1 Anti-inflammatory activity of methanolic extract in RAW $\mathbf{2 6 4 . 7}$ macrophage cells. RAW 264.7 cells were induced using LPS/IFN- $\gamma$. L-NAME $(250 \mu \mathrm{M})$ and induced cell represented a positive and negative control respectively. Each histogram represents a mean of three replicates with error bar representing the standard deviation. ${ }^{*}$ Indicates significant difference $(P<0.05)$ compared to the positive control. 


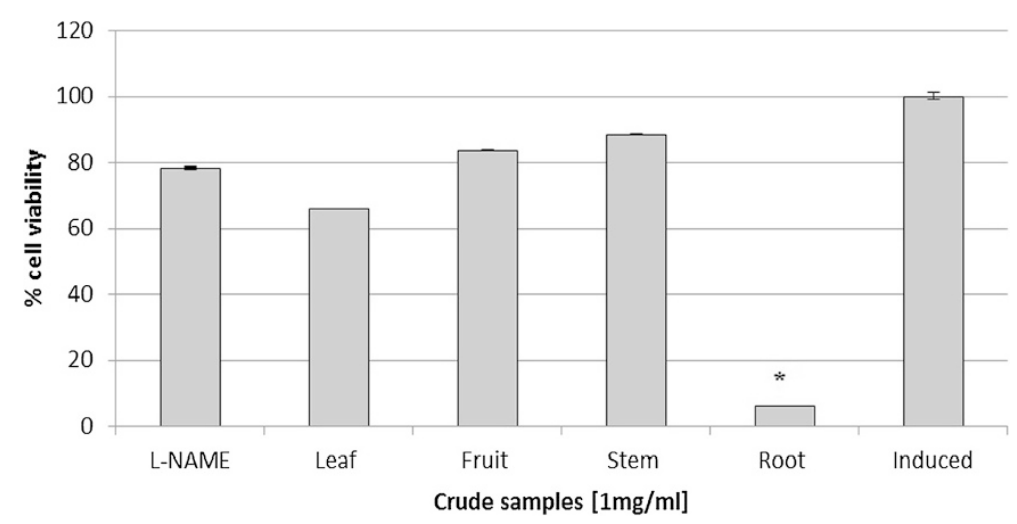

Figure $\mathbf{2}$ Cytotoxic activity of methanolic extract of different parts of $\boldsymbol{J}$. curcas plant using MTT assay. L-NAME (250 $\mu$ M) and induced cell represented positive and negative control respectively. Each histogram represents a mean of three replicates with error bar representing the standard deviation. *Indicates significant difference $(\mathrm{P}<0.05)$ compared to the positive control.

higher $(\mathrm{P}<0.05)$ than the other fractions. The values for water, chloroform, ethyl acetate and hexane were $0.69 \mathrm{mg} \mathrm{GAE} / \mathrm{g} \mathrm{dw}, 0.15 \mathrm{mg} \mathrm{GAE} / \mathrm{g} \mathrm{dw}, 0.15 \mathrm{mg} \mathrm{GAE} / \mathrm{g}$ $\mathrm{dw}$ and $0.13 \mathrm{mg} \mathrm{GAE} / \mathrm{g} \mathrm{dw}$, respectively.

\section{Anti-inflammatory screening of crude extract}

Anti-inflammatory activity was evaluated using the methanolic extract from different parts of $J$. curcas. Crude extract from root gave 100\% of inhibition towards nitric oxide production (Figure 1). Cytotoxicity test using MTT assay showed that crude extract from root gave the highest inhibition towards cell growth. Almost $95 \%$ of the cell growth was inhibited by the crude extract (Figure 2).

\section{Liquid-liquid partition yield}

Approximately $6.4 \mathrm{~g}$ of crude extract was obtained from $10 \mathrm{~g}$ root sample. Liquid-liquid partition produced extract of hexane, chloroform, ethyl acetate and water at $200 \mathrm{mg}$, $2.6 \mathrm{~g}, 1.7 \mathrm{~g}$ and $1.8 \mathrm{~g}$, respectively (Figure 3 ).

\section{Anti-inflammatory screening of root extract partition}

Anti-inflammatory activity was carried out using different solvent partitions of $J$. curcas root. Among the four partitions tested, hexane fraction showed the highest inhibition followed by chloroform, water and ethyl acetate with values significantly different $(\mathrm{P}<0.05)$ compared to the positive control (Figure 4). A cytotoxicity test by

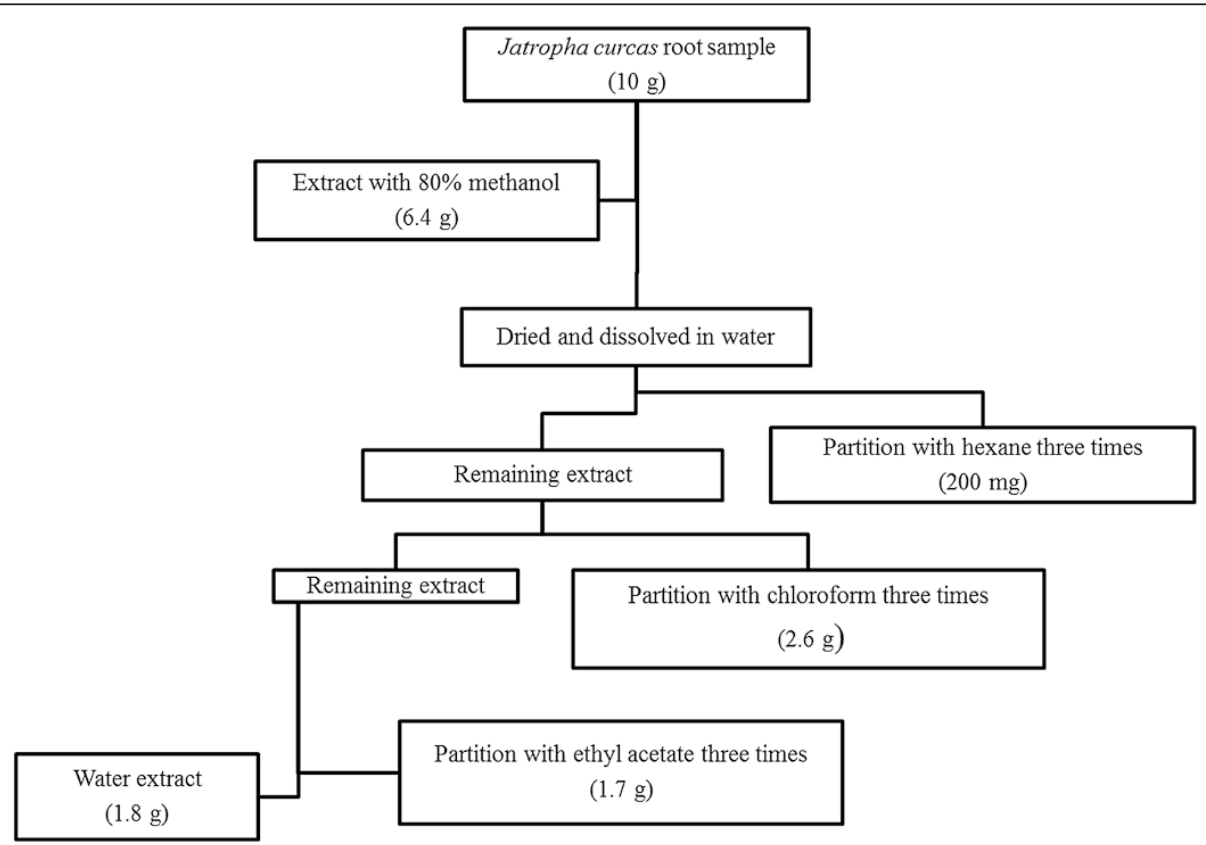

Figure 3 A flowchart of a liquid-liquid partition step of a crude extract from J. curcas root. Dry weight of samples obtained is stated in the flowchart. 


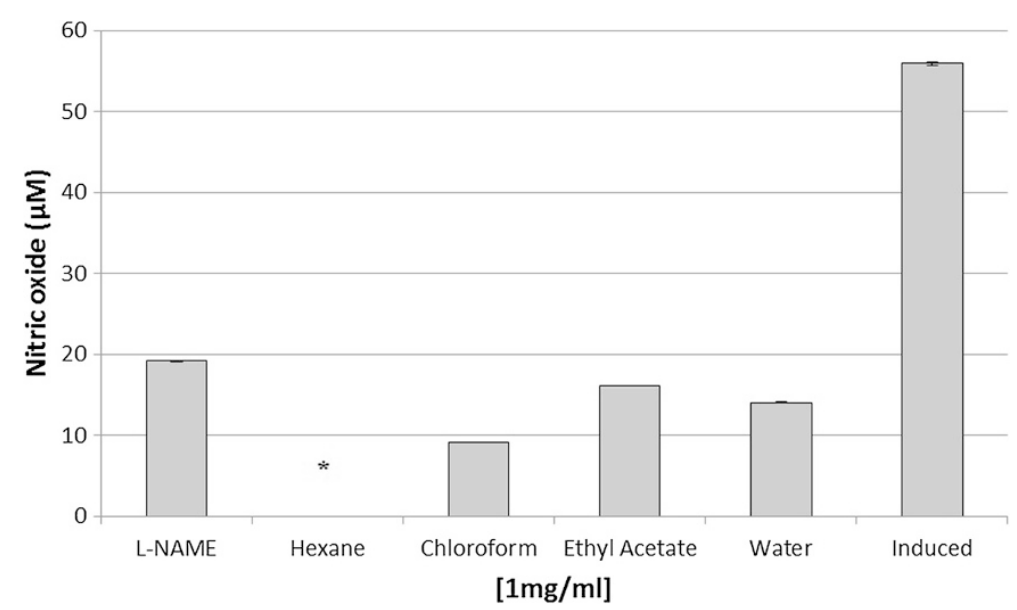

Figure 4 Anti-inflammatory activity of different solvent partitions. Crude extract from root was subjected to liquid-liquid fractionation process. Each partition was subjected to anti-inflammatory test. L-NAME $(250 \mu \mathrm{M})$ and induced cell represented a positive and negative control respectively. Each histogram represents a mean of three replicates with error bar representing the standard deviation. *Indicates significant difference $(P<0.05)$ compared to the positive control.

MTT assay showed hexane partition produced the highest inhibition towards cell growth, whereas other partitions exhibited no cytotoxicity effect (Figure 5). Analysis of the hexane partition by GC-MS indicated the presence of various compounds mainly polycyclic aromatic hydrocarbons and fatty acid derivatives (Table 3). A number of these compounds were terpenoids such as 17 alphahydroxypregnenolone, bicyclo[4.2.0] oct-1-ene, 2-methyl7-exo-phenyl and gamma-sitosterol.

\section{Anti-inflammatory assay of isolated compounds}

Hexane fraction was chosen as it showed both antiinflammatory and cytotoxicity activities for column chromatography analysis using silica gel $(0.06-0.2 \mathrm{~mm} / 70$ 230 Mesh ASTM). The separation produced five single spots, labeled as $\mathrm{H}-1$ to $\mathrm{H}-5$. Spot $\mathrm{H}-4$ and $\mathrm{H}-5$ showed strong inhibition towards nitric oxide production by RAW 264.7 murine macrophage cells, while spots labeled as $\mathrm{H}-$ 1 and $\mathrm{H}-(2 \& 3)$ showed lower inhibition when compared to the positive control (Figure 6). Cytotoxicity test using MTT assay showed no inhibition towards cell growth for all spots (Figure 7).

\section{GC-MS analysis of active compounds}

The active compounds present in the spots $\mathrm{H}-4$ and $\mathrm{H}-5$ were analyzed using GC-MS and identified based on the database in the GC-MS library. The major groups of these spots were fatty acids. Phenolic compounds also exist as a minor component in this particular fraction. The H-4 spot showed two major peaks (29 and 50) at

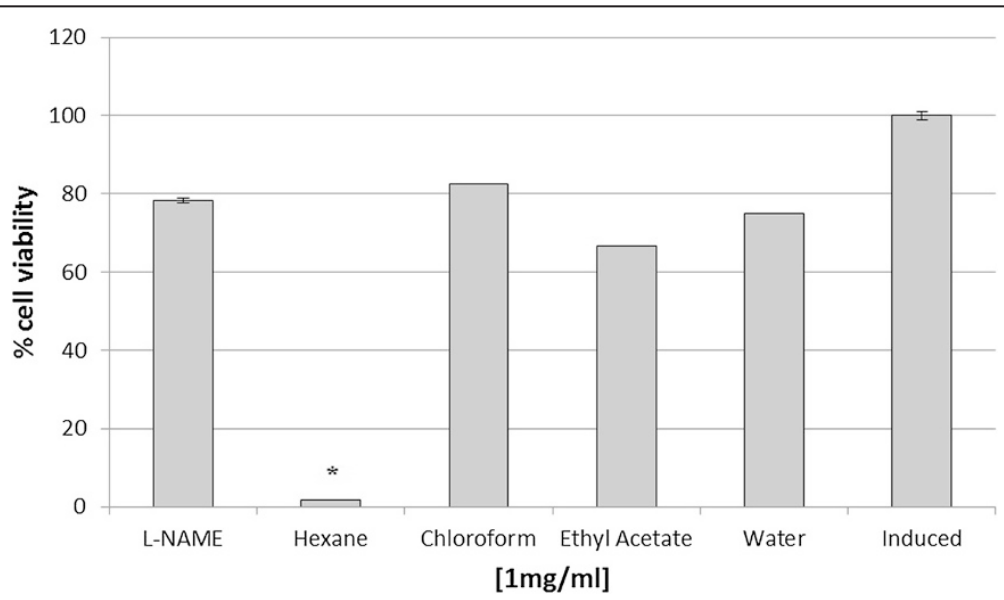

Figure $\mathbf{5}$ Cytotoxic activity of different solvent partitions of root by MTT assay. L-NAME $(250 \mu \mathrm{M})$ and induced cell represented a positive and negative control respectively. Each histogram represents a mean of three replicates with error bar representing the standard deviation. *Indicates significant difference $(P<0.05)$ compared to the positive control. 
Table 3 The major compounds detected in hexane fraction by GC-MS analysis

\begin{tabular}{lll}
\hline No & Compound name & Percentage area \\
\hline 1 & 9-Octadecanoic acid, methyl ester & 2.22 \\
2 & Bicyclo[4.2.0]oct-1-ene, 2-methyl-7-exo-phenyl* & 10.79 \\
3 & $\begin{array}{l}\text { 5-[2-(4,5,5-Trimethyl-cyclopent-1-enyl)ethylidene] } \\
\text { pyrimidine-2,4,6(1H,3H,5H)-trione* }\end{array}$ & 8.94 \\
4 & 9-Methyl-S-octahydrophenanathracene* & 2.69 \\
5 & 17.alpha-Hydroxypregnenolone* & 7.57 \\
6 & Delta-Selinene* & 2.65 \\
7 & 4a.alpha, 4b.beta-Gibbane-1.alpha10. & 2.72 \\
& beta-dicarboxilic acid* & 3.55 \\
8 & 2,4-Bis(dimethylbenzyl)-6-t-butylphenol* \\
9 & Phenol, 2,4-bis(1-methyl-1-phenyl)* & 2.42 \\
10 & 1,2-Benzenedicarboxilic acid, & 9.95 \\
& mono(2-ethylhexyl) ester* & \\
11 & Decanedioic acid,bis(2-ethylhexyl) ester & 6.69 \\
12 & Gamma-Sitosterol* & 2.79 \\
\hline
\end{tabular}

*polycyclic aromatic hydrocarbon derivatives.

retention times of 10.875 and 13.559 minutes and were identified as hexadecanoic acid methyl ester and 9octadecanoic acid methyl ester, respectively (Figure 8 ). The H-5 spot showed three major peaks (33, 46 and 50) and identified as hexadecanoic acid methyl ester, 9octadecanoic acid methyl ester and octadecanoic acid, respectively (Figure 9).

\section{Discussion}

Among the plant parts of $J$. curcas, leaves showed the highest amount of phenolics expressed in milligram of gallic acid equivalent (mgGAE/g dw), followed by root, fruits and stem. Similarly, it was reported that leaves of J. curcas contained the highest amount of phenolic compounds, but not for roots and stem part where phenolic content for stem was higher than that of roots [7].

It has been reported that phenolic compounds with various biological activities are commonly produced by plants. Phenolic compounds extracted from Gastrodia elata root showed an antioxidant property [11], while phenolic compounds extracted from Nymphaea mexicana Zucc showed an anti-inflammatory property towards induced RAW 264.7 macrophage cells [12]. It has been suggested that the anti-inflammatory property of the phenolic compounds was due to their scavenging activities on the reactive oxygen species or reactive nitrogen species [13].

The effectiveness of $J$. curcas root in anti-inflammatory activity had been reported by in vivo studies. It has been shown [8] that the root extract could reduce formalin induced paw edema in rat. Later, Nayak and Patel [14] compared root, stem and leaf extracts of $J$. curcas in anti-inflammatory activity study towards carrageenaninduced rat paw edema. Groups of albino rats were injected by inflammation inducer (carrageenan) and the levels of inflammation mediators (histamine, serotonin and kinin) were monitored. Their results showed that root extract inhibited histamine, serotonin and kinin released up to $70 \%$ - $80 \%$ compared to leaf $(50 \%-55 \%)$ and stem $(40 \%-45 \%)$. However, these studies did not indicate the nature of compounds involved in the antiinflammatory activity.

It was also observed that, root extract also exhibited a high cytotoxicity activity towards RAW 264.7 cells growth. A similar finding was also reported [7] where a series of different concentrations of methanolic extract

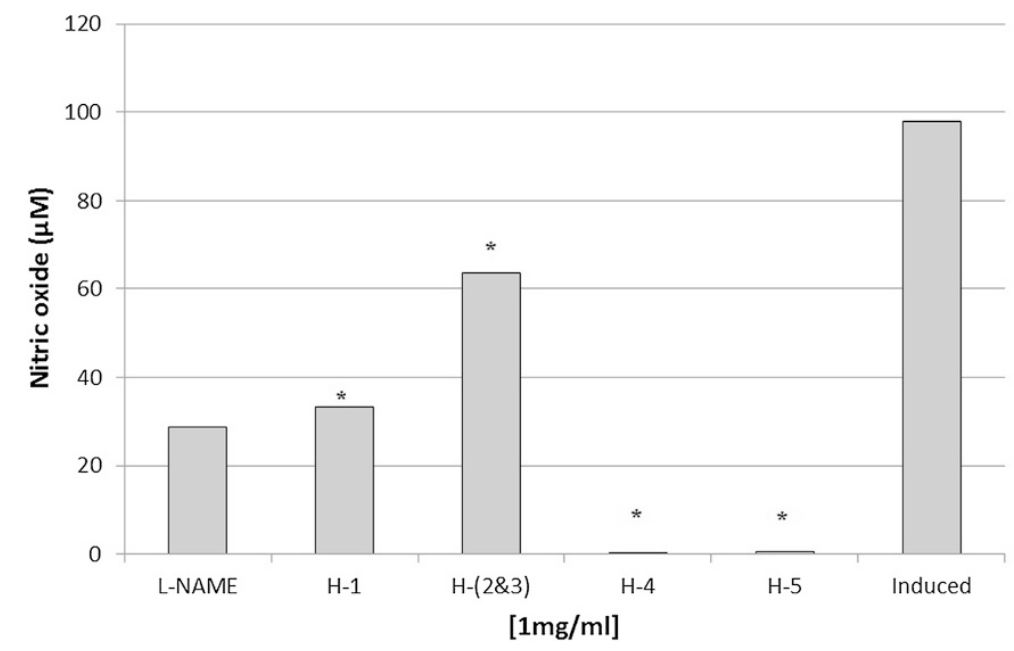

Figure 6 Anti-inflammatory activity of different spots isolated from hexane fraction. Spot $\mathrm{H}-(2 \& 3)$ consisted of two partially overlapped spots. Spot $\mathrm{H}-4$ and $\mathrm{H}-5$ showed high anti-inflammatory activity. L-NAME $(250 \mu \mathrm{M})$ and induced cell represented a positive and negative control respectively. Each histogram represents a mean of three replicates with error bar representing the standard deviation. ${ }^{*}$ Indicates significant difference $(P<0.05)$ compared to the positive control. 


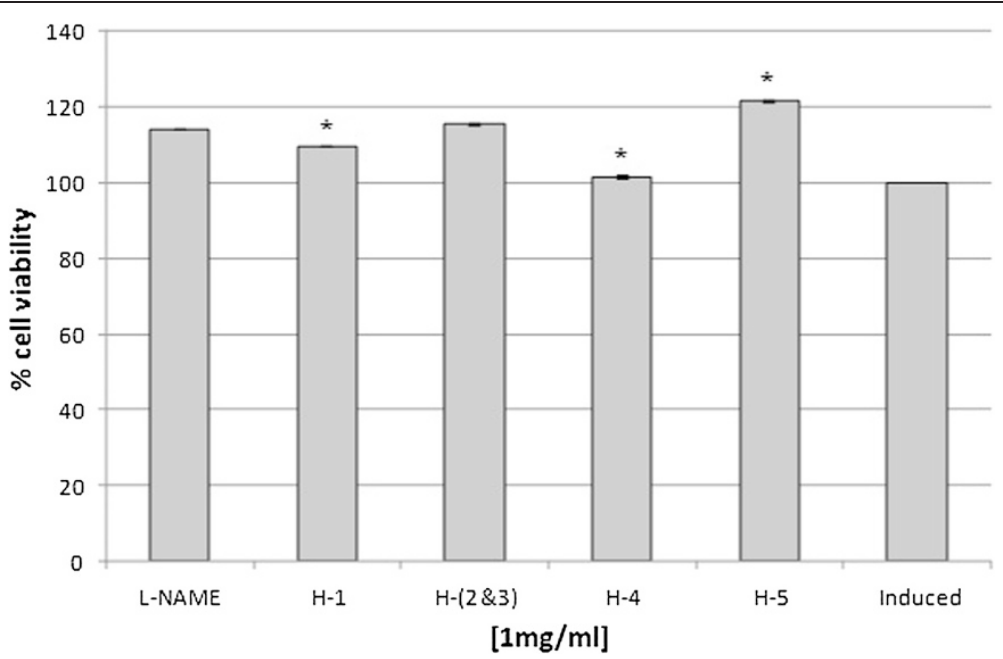

Figure 7 Cytotoxic activity of different spots isolated from hexane partition using MTT assay. All spots showed no toxicity effect towards RAW 264.7 cells growth. L-NAME $(250 \mu \mathrm{M})$ and induced cell represented a positive and negative control respectively. Each histogram represents a mean of three replicates with error bar representing the standard deviation. *Indicates significant difference $(P<0.05)$ compared to the positive control.

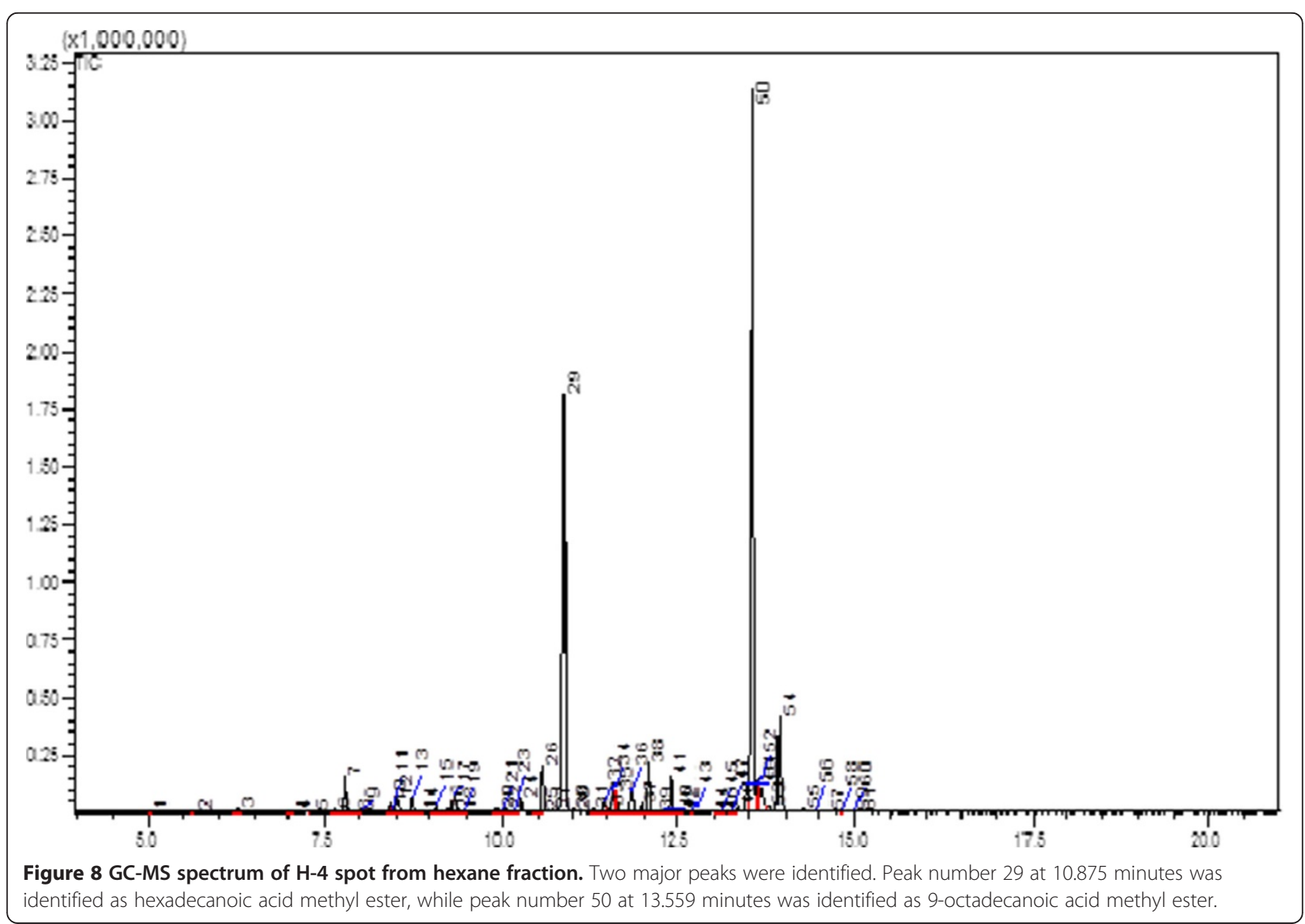




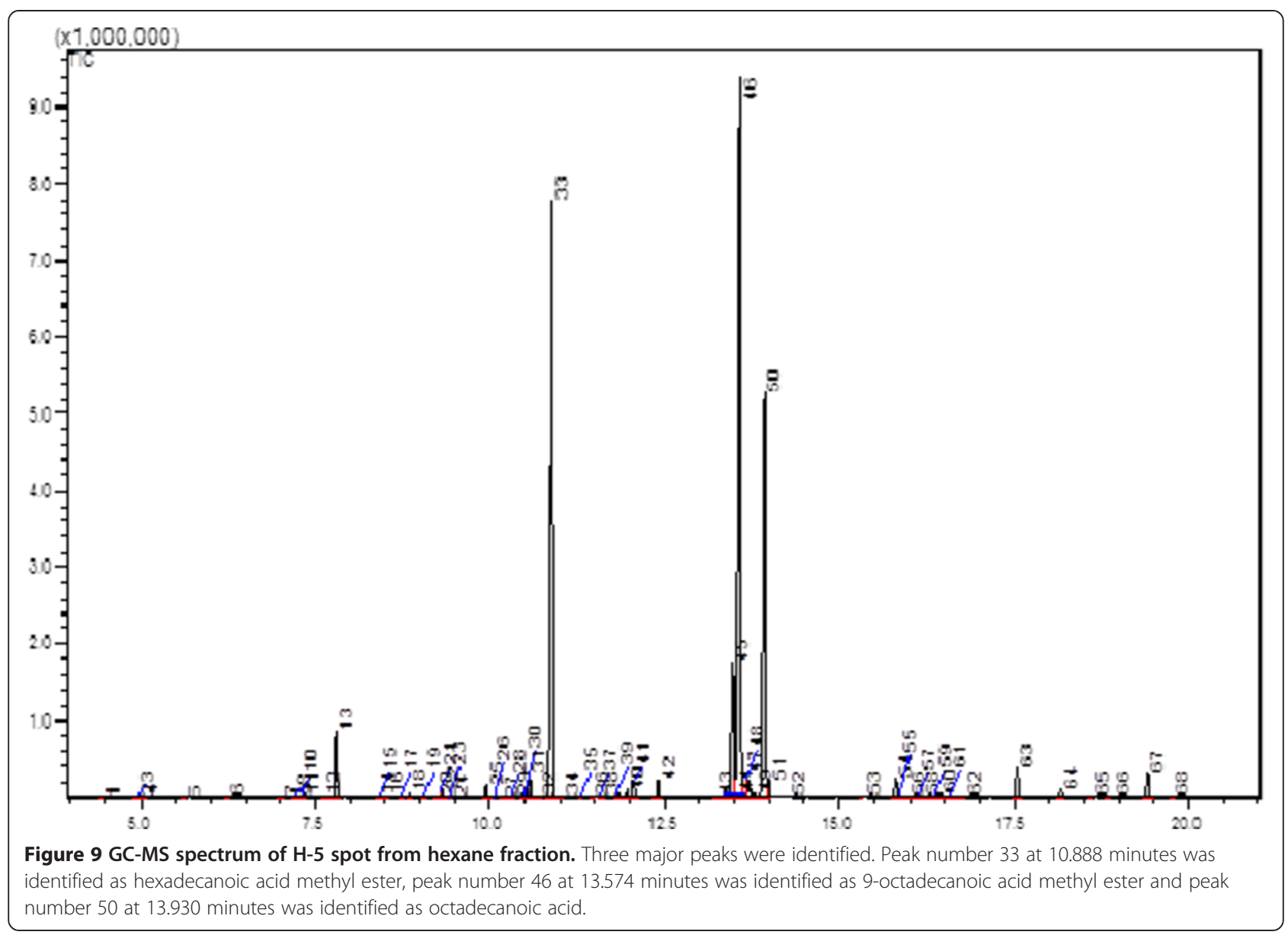

of $J$. curcas root showed growth inhibition of cells in a dose-dependent manner. At this point, it was not certain whether the anti-inflammatory activity was due to cell death or genuine inhibitory effect of the compounds present in the extract or that the extract contained compounds with anti-inflammatory as well as cytotoxicity activities. It was also interesting to note that, in the present study, methanolic extract of J. curcas roots which contained lower phenolic compounds compared to that of leaves extract, showed the highest anti-inflammatory activity towards RAW 264.7 cells. This indicated that root extract may contain non-phenolic compounds with antiinflammatory activity.

Further purification conducted by liquid-liquid partition separated the root crude extract into four fractions based on the different solvent polarities. Among the four solvents, water fraction showed the highest phenolic content (0.69 mg GAE/g dw), while chloroform, ethyl acetate and hexane fractions showed similar levels $(0.13-0.15 \mathrm{mg}$ $\mathrm{GAE} / \mathrm{g} \mathrm{dw)}$. Although all partitions showed an inhibition towards nitric oxide production in RAW 264.7 cells, the hexane fraction showed the highest inhibitory activity. Again, this finding indicated that other non-phenolic compounds may be involved in the anti-inflammatory activity. Previous studies had reported the anti-inflammatory activity of the non-polar solvent extracts from various plants species. For example, ethyl acetate fraction of Ochna squarrosa L. showed a higher anti-inflammatory activity when compared to diclofenac sodium [15]. Another report showed that the anti-inflammatory activity of the hexane extract of Alchornea cordifolia was better than indomethacin in an in vivo study [16]. Several other reports also observed that a non-polar extract from Urtica dioica L. and Acalypha indica exhibited an antiinflammatory property $[17,18]$. Their results augur well with the findings of the present study where hexane fraction showed the strongest inhibition, indicating nonpolar compounds were involved.

However, the hexane fraction was also found to be toxic towards RAW 264.7 cells. GC-MS analysis of the hexane fraction showed the presence of several compounds belonging to the terpenoid groups such as $5-[2-(4,5,5-$ trimethyl-cyclopent-1-enyl)ethylidene]pyrimidine-2,4,6 $(1 \mathrm{H}, 3 \mathrm{H}, 5 \mathrm{H})$-trione;1,2-benzenedicarboxilic acid, mono (2-ethylhexyl) ester and bicyclo[4.2.0]oct-1-ene, 2-methyl7-exo-phenyl. Terpenoids have been claimed in several 
reports to have cytotoxicity effects towards animal cells lines. Terpenoid compounds commonly found abundant in plants exhibited anti-cancer property by killing the cancer cells [19]. A report using J. curcas seed kernel extract showed that the extract which contained terpenoid compounds inhibited breast cancer cells (MCF-7) and cervical cancer (HeLa) growth in a dose-dependent manner [20]. Other studies have also reported the cytotoxicity effect of terpenoid compounds on cancer as well as normal cells growth. A cytotoxicity test of terpenoid compounds showed total growth inhibition of normal green monkey kidney cells (VERO) at $0.21 \mu \mathrm{g} \cdot \mathrm{mL}^{-1}$ [21].

Further separation procedures by the open system column chromatography produced five spots, which were non-toxic towards RAW 264.7 cell lines. However, only two spots $(\mathrm{H}-4, \mathrm{H}-5)$ gave positive results towards antiinflammatory activity. This indicated that the cytotoxic compounds present in hexane extract were successfully separated from the anti-inflammatory metabolites. The separation was probably due to terpenoids being un-eluted as they bound strongly to the silica gel column because of their polarities.

Identification of the active compounds present in spots $\mathrm{H}-4$ and $\mathrm{H}-5$ by GC-MS revealed the presence of long chain fatty acids as the major compounds. The three major fatty acids identified by GC-MS were hexadecanoic acid methyl ester, 9-octadecanoic acid methyl ester and octadecanoic acid. Several reports have claimed that saturated fatty acids are involved in regulating antiinflammatory pathway [22,23]. An enzyme kinetic study [23] proved that saturated fatty acid acted as a competitive inhibitor towards phospholipase $\mathrm{A}_{2}$, an enzyme involved in catalyzing the release of arachidonic acid, a precursor for the synthesis of inflammatory cytokine at $s n$-2 position of membrane phospholipid [24,25]. The absence of terpenoid compounds in the active spots strongly supported the above suggestion that the cytotoxicity effect was due to the presence of terpenoid compounds in the samples.

\section{Conclusion}

In conclusion, the present study demonstrated that among the different parts of $J$. curcas plant, the root extract showed the highest anti-inflammatory activity in RAW 264.7 macrophage cell lines. However, the hexane fraction of $J$. curcas root extract possessed both anti-inflammatory and cytotoxicity activities. The non-polar compounds present in the hexane fraction analyzed by GC-MS consisted of terpenoids which may contribute to the cytotoxicity activity. A further purification step by column chromatography of the hexane fraction produced non-cytotoxic metabolites with anti-inflammatory activity. These metabolites analyzed by GC-MS were identified as hexadecanoic acid methyl ester, 9-octadecanoic acid methyl ester and octadecanoic acid.

\section{Abbreviations}

GC-MS: Gas chromatography mass spectrophotometer; DMEM: Dubelco's modified eagle media; FBS: Fetal bovine serum; IFN-ץ: Interferon-gamma; LPS: Lipopolysaccharide; L-NAME: N-nitro-L-arginine-methyl ester; iNOS: Inducible nitric oxide synthase; MTT: 3-(4,5-dimethylthiazol-2-yl)-2,5-diphenyltetrazolium bromide; EtOAc: Ethyl acetate; TLC: Thin layer chromatography; UV: UltraViolet; GAE: Gallic acid equivalent.

\section{Competing interests}

The authors declare that they have no competing interests.

\section{Authors' contributions}

ARO carried out all the experiments. SA was involved in cell culturing and MTT assay techniques. ISI was involved in GC-MS analysis and NA was involved in securing the research fund and finalizing the manuscript. ARO, NA, SA, ISI and MPZ were involved in data analysis. All authors have read and approved the final manuscript.

\section{Acknowledgement}

The authors would like to acknowledge the research grant provided by the Ministry of Education, Malaysia under the Fundamental Research Grant Scheme (FRGS) (No: 01-01-12-1095 FR) and Universiti Putra Malaysia for the facilities. The authors would like to thank Dr. Shamsul Khamis and Tuan Haji Mohd Shahril Ab. Rahman for their invaluable technical assistance and advice.

\section{Author details}

${ }^{1}$ Laboratory of Natural Product, Institute Bioscience, Universiti Putra Malaysia, 43400 Serdang, Selangor, Darul Ehsan, Malaysia. ${ }^{2}$ Department of Biochemistry, Faculty of Biotechnology and Biomolecular Sciences, Universiti Putra Malaysia, 43400 Serdang, Selangor, Darul Ehsan, Malaysia. ${ }^{3}$ Institute Of Tropical Agriculture Universiti Putra Malaysia, 43400 UPM Serdang, Selangor, Darul Ehsan, Malaysia. ${ }^{4}$ Department of Chemistry, Faculty of Science, Universiti Putra Malaysia, 43400 UPM Serdang, Selangor, Darul Ehsan, Malaysia. ${ }^{5}$ Department of Environmental Sciences, Faculty of Environmental Studies, Universiti Putra Malaysia, 43400 UPM Serdang, Selangor, Darul Ehsan, Malaysia.

Received: 3 September 2014 Accepted: 16 January 2015

Published online: 05 February 2015

\section{References}

1. Navesh K, Sushil K. Jatropha curcas L. Silviculture and Use. 2nd ed. India: Agro-Bios; 2006.

2. León FV, Irma DF, Holger M, Rosa T, Alfonso Z, Abraham JV, et al. Evaluation of the wound-healing activity of selected traditional medicinal plants from Peru. J Ethnopharmacol. 1997:55:193-200.

3. Carla WS, Norizan A, Faridahanim MJ, Sahidin I. Medicinal property, phytochemistry and pharmacology of several Jatropha species (Euphorbiaceae): a review. Phytochemistry. 2013;85:7-29.

4. Kulkarni ML, Sreekar H, Keshavamurthy KS, Nivedita S. Jatropha Curcas-Poisoning Indian J Pediatr. 2005;72(1):75-6.

5. Ritesh GM, Nageshkumar GR, Suman SK, Asha K, Shahnavaz M, Pillay W. Jatropha Curcas Poisoning. Indian J Pediatr. 2006;73(7):634.

6. Luciano AP, Beatriz RC, Antônio FD, Rosane MTM, Franklin RC. Poisoning by Jatropha ribifolia in goats. Toxicon. 2012;59:587-91.

7. Ehsan O, Norhani A, Wan ZS, Abdul RO, Syahida A, Wen BK, et al. Antioxidant, anti-inflammatory and anticancer activities of methanolic extracts from Jatropha curcas Linn. J Med Plants Res. 2011;5(1):49-57.

8. Mujumdar AM, Misar AV. Anti-inflammatory activity of Jatropha curcas roots in mice and rats. J Ethnopharmacol. 2004;90:11-5.

9. Rajbir K, Saroj A, Bikram S. Antioxidant activity of the phenol rich fractions of leaves of Chukrasia tabularis A. Juss. Bioresour Technol. 2008;99:7692-8.

10. Syahida A, Israf DA, Lajis NH, Khozirah S, Habsah M, Jasril, et al. Effect of compound isolated from natural products on IFN- $\gamma /$ LPS-induced nitric oxide production in RAW 246.7 macrophage. Pharm Biol. 2006;44(1):50-9.

11. Lee JY, Jang YW, Kang HS, Moon H, Sim SS, Kim CJ. Anti-inflammatory action of phenolic compounds from Gastrodia elata root. Arch Pharm Res. 2006;29(10):849-58.

12. Hsu CL, Fang SC, Yen GC. Anti-inflammatory effects of phenolic compounds isolated from the flowers of Nymphaea mexicana Zucc. Food and Funct. 2013;4(8):1216-22. 
13. Sergent T, Piront N, Meurice J, Toussaint O, Schneider YJ. Anti-inflammatory effects of dietary phenolic compounds in an in vitro model of inflamed human intestinal epithelium. Chem Biol Interact. 2010;188(3):659-67.

14. Nayak BS, Patel KN. Anti-Inflammatory screening of Jatropha curcas root, stem and leaf in albino rats. Rom J Biol -Plant Biol. 2010;55:9-13.

15. Anuradha V, Pullela VS, Ranga RR, Manjulatha K, Muralidhar GP, Rao JM. Isolation and synthesis of analgesic and anti-inflammatory compounds from Ochna squarrosa L. Bioorg Med Chem. 2006;14:6820-6.

16. Mavar-Manga H, Haddada M, Pieters L, Baccelli C, Penge A, Quetin-Leclercq J. Anti-inflammatory compounds from leaves and root bark of Alchornea cordifolia (Schumach. \& Thonn.) Müll. Arg. J Ethnopharmacol. 2008;115:25-9.

17. Sabzar AD, Yousuf AR, Farooq AG, Poonam S, Naresh K, Rambir S. Bioassay guided isolation and identification of anti-inflammatory and anti-microbial compounds from Urtica dioica L. (Urticaceae) leaves. Afr J Biotechnol. 2012;11(65):12910-20.

18. Reddy TRP, Rao RSV, Swamy AVN, Reddanna P, Reddy GP, Reddy DVR. Exploring the anti-inflammatory and anti-cancer compounds from the leaves of Acalypha indica. IOSR. J Pharm Biologic Sci. 2012;4(2):01-7.

19. Rakshit KD, Harinder PSM, Klaus B. Jatropha Diterpenes: a review. J Am Oil Chem Soc. 2011;87:697-704.

20. Ehsan O, Abdullah N, Syahida A, Wan ZS, Abdul RO, Yin WH. Bioactive compounds and biological activities of Jatropha curcas L. kernel meal extract. Int J Mol Sci. 2011;12:5955-70.

21. de S Fernandes E, Rodrigues FA, Tófoli D, Imamura PM, de Carvalho JE, Ruiz ALTG, et al. Isolation, structural identification and cytotoxic activity of hexanic extract, cyperenoic acid, and jatrophone terpenes from Jatropha ribifolia roots. Rev Bras Farmacogn Braz J Pharmacog. 2013;23(3):441-6.

22. Rajeswari G, Murugan M, Mohan VR. GC-MS analysis of bioactive components of Hugonia mystax L. (Linaceae). Res J Pharm Biol Chem Sci. 2012;3(4):301.

23. Vasudevan A, Kalarickal VD, Pradeep KM, Ponnuraj K, Chittalakkottu S, Madathilkovilakathu H. Anti-inflammatory property of n-hexadecanoic acid: structural evidence and kinetic assessment. Chem Biol Drug Des. 2012;80(3):434-9.

24. Ichiro K, Makoto M. Phospholipase $A_{2}$ enzymes. Prostag oth Lipid Mediat. 2002;68-69:3-58

25. Bruno LD, Jonathan PA. Phospholipase $A_{2}$. Prostag, Leukot Essent Fatty Acids. 2003;69:87-97.

\section{Submit your next manuscript to BioMed Central and take full advantage of:}

- Convenient online submission

- Thorough peer review

- No space constraints or color figure charges

- Immediate publication on acceptance

- Inclusion in PubMed, CAS, Scopus and Google Scholar

- Research which is freely available for redistribution 